\title{
Discussion on the Reform of Practical Teaching and Talent Training Mode in Local Colleges and Universities
}

\author{
Renbao Liu* \\ School of Public Management \\ Shandong Institute of Business and Technology \\ Yantai, China \\ Email: liurbhy@163.com
}

\begin{abstract}
This paper focuses on how local colleges and universities can cultivate applied and composite talents with innovative spirit and innovation ability to meet the needs of social and economic development. The methods and ways include strengthening the practical teaching links and increasing the management and investment in practical teaching construction, enhancing the teaching research, optimizing and adjusting the professional structure of disciplines, perfecting talent training programs, establishing an innovation platform for talent training as well as strengthening the construction of teaching staff in practical teaching. We expect through the reform of practice teaching and talent training mode, to cultivate students' innovation spirit and innovation ability in the whole process of teaching, and improve the quality of teaching. The innovation of the paper is to put forward the methods and ways of cultivating college students' innovative spirit and innovation ability from the perspective of the reform of practical teaching and talent training mode.
\end{abstract}

Keywords-local colleges and universities; practical teaching; talent training mode; teaching quality

\section{INTRODUCTION}

Strengthening quality education focusing on innovative quality is the general trend of education development in the world today. In order to meet the demand for talent structure, types and specifications for social and economic development, and strive to cultivate applied and compound talents with innovative spirit and innovation ability ${ }^{[1]}$, local colleges and universities should further deepen the teaching reform, adhere to the combination of education and social practice, and fully implement quality education. Local colleges and universities should focus on cultivating students' innovative spirit and innovation ability, bringing up qualified talents with comprehensive development of morality, intelligence, physique and aesthetic education who are "qualified, moral, cultural and disciplined" ${ }^{[2]}$. The practice link is an important teaching link to train the students' creative spirit and innovation ability. In the undergraduate teaching work, local colleges and universities should insist on changing the education concept as the guide, reform the teaching contents and strengthen practical teaching as the core, and train the students' innovative spirit and innovation ability in the whole process of teaching ${ }^{[3]}$. All kinds of teaching practice activities should fully reflect the application of knowledge, highlight the dominant position of students in the process of practice teaching, emphasize the independence, design and creativity of practice teaching ${ }^{[4]}$, meticulously cultivate students' interest and confidence in research issues, create a unity of students' knowledge, ability and quality and effectively improve students ability to adapt to economic construction, social development and technological progress $^{[5]}$.

II. STRENGTHEN THE PRACTICAL TEACHING LINKS, AND INCREASE THE MANAGEMENT AND INVESTMENT IN PRACTICAL TEACHING CONSTRUCTION

\section{A. Practically regulate and improve the laboratory construction}

In accordance with the development ideas of scale, structure, quality and benefits of a new stage and the relevant requirements of the Ministry of Education, we should concentrate our efforts on the construction of laboratories and conditions, so as to provide a good material guarantee for improving teaching standards and educating people's quality.

\section{B. Establish and improve the practice teaching base inside and outside the school}

The departments should ensure that all kinds of practical activities are carried out according to plan, and the students should be organized step by step to carry out field teaching, cognition practice, graduation practice or graduation design to the established practical teaching base.

The departments should build a relatively stable outside school practice base, improve the practice conditions, and perfect the rules and regulations of the practice management ${ }^{[6]}$.

\section{ENHANCE THE TEACHING RESEARCH AND PROMOTE NEW PROGRESS OF TEACHING}

Teaching research is the need of schools to further deepen the teaching reform and update the teaching content and teaching methods. It is an important measure to improve the teaching level and ability of teachers and update the structure of teachers' knowledge and improve the quality of teachers. Moreover, it is an important guarantee for schools to improve the teaching level and the quality of education. We should strengthen the awareness of teaching research to carry out teaching plans in a planned and organized manner, standardize 
the contents of teaching research in light of the practice of personnel training, attach importance to teaching research project, improve the level of teaching research, take incentive policies and measures to encourage teaching and research, rely on teaching research center and actively carry out teaching research work.

Teaching research should aim at cultivating "high level applied type" talents to meet the needs of the modernization of our country in the new century, and deeply study the training mode and specification, discipline and specialty construction, teaching content and curriculum system, practical teaching content and system, teaching method and hand section, teaching mode and so on. Based on the teaching practice, teaching research should further master the teaching rules of different majors and courses, update the teaching content, reform the teaching methods, and make a high starting point, a new idea and a breakthrough in the teaching work, and promote the new development of the school teaching work with a high level of teaching research.

IV. OPTIMIZE AND ADJUST THE PROFESSIONAL STRUCTURE OF DISCIPLINES TO MEET THE NEEDS OF LOCAL ECONOMIC AND SOCIAL DEVELOPMENT

We should follow the laws of higher education and market economy, face the market and take the initiative to adapt to the new requirements for the economic and social development for the training of senior specialized talents, form the flexible regulation mechanism of discipline, the self-adaptation mechanism of the school, the prediction mechanism of talent demand, the policy guarantee and the evaluation and supervision mechanism and strive to form a professional system of structural optimization, rational layout, and distinctive disciplines.

We should also face the development of local economy and society, adhere to the needs of social talent, and aim at improving the level of discipline, optimize the allocation of resources, adjust disciplines and broaden the space for professional development. We should organically combine the support of the dominant disciplines and basic disciplines with the development of applied disciplines, giving priority to the development of key and predominant disciplines, transforming and upgrading traditional disciplines, and actively developing the disciplines that the society desperately needs. ${ }^{[7]}$. We should vigorously develop the disciplines of emerging industries, pillar industries and advantageous industries, and vigorously develop new specialties that can promote industrial development and employment for internationalization, urbanization and modernization. In addition, according to the regional development of high-tech industries, we should work closely with large enterprise groups and research institutes to do a good job in professional co-building, actively develop related disciplines and majors, and train specialized talents that meet the requirements of the new industrialization road and optimize the industrial structure.

\section{PeRfECt TALENT TRAINING PROGRAMS, IMPLEMENT DIVERSIFIED TALENT TRAINING MODE}

\section{A. Do a good job of revising and perfecting the talent training program}

The colleges should do a good job in revising and improving the talent training programs of all professionals, so that talent training programs can become the basis for scientific training of high-quality talents. The process of talent training should further expand the extension of practical teaching, from the internal relations between various teaching practices and theoretical teaching and the requirements of students' intelligence structure. We will draw up syllabus and plan for all kinds of practical teaching links and bring the practical talent training programs into innovative talent training system.

TABLE I. A LIST OF PRACTICAL TEACHING LINKS

\begin{tabular}{|c|c|c|}
\hline $\begin{array}{c}\text { Main } \\
\text { Categories }\end{array}$ & Contents & Hours and Credits \\
\hline \multirow{8}{*}{$\begin{array}{l}\text { professional } \\
\text { practice }\end{array}$} & Experiment course & Independent setting \\
\hline & Lesson experiment & \\
\hline & Understanding practice & 1-2 weeks, 1 credit \\
\hline & Practical training & \\
\hline & Curriculum design & \\
\hline & Term paper & 1 credit \\
\hline & $\begin{array}{l}\text { Graduation practice and } \\
\text { graduation thesis } \\
\text { (Design) }\end{array}$ & $\begin{array}{l}\text { No less than } 8 \text { weeks, } 4 \\
\text { credits for graduation } \\
\text { practice and } 6 \text { credits for } \\
\text { graduation thesis(Design) }\end{array}$ \\
\hline & Professional competition & 2 credits \\
\hline \multirow[b]{2}{*}{$\begin{array}{l}\text { second } \\
\text { classroom } \\
\text { practice }\end{array}$} & Military training & $\begin{array}{l}\text { Military theory, centralized } \\
\text { arrangement for } 2 \text { weeks, } 1 \\
\text { credit }\end{array}$ \\
\hline & $\begin{array}{l}\text { Ideological growth, } \\
\text { employment and } \\
\text { entrepreneurship, } \\
\text { innovation and creation, } \\
\text { social practice, } \\
\text { voluntary public } \\
\text { welfare, literature and } \\
\text { art, physical and mental } \\
\text { emotion, work } \\
\text { experience, skills } \\
\text { expertise, labor } \\
\text { practices, etc. }\end{array}$ & Total 10 credits \\
\hline
\end{tabular}

All colleges should increase the hours of practical teaching and improve the credit requirements for practical teaching. The proportion of practical credits for humanities and social sciences must reach more than $20 \%$, and the proportion of practical credits for science and engineering majors should exceed $30 \%$. The colleges should promote the reform and innovation of experimental content and experimental models, increase the proportion of comprehensive and design experiments, and enhance the proportion of open experiments and self-selection experiments.(TABLE I).

\section{B. Actively explore the innovation of talent training mode}

We should promote the comprehensive reform of the personnel training model in the teaching content, curriculum system, and practice aspects of the school, implement a variety 
of personnel training modes such as order-based personnel training, disciplinary major training, 2+2, and 3+1 personnel training and strive to cultivate all kinds of talents that meet the needs of social and economic development.

\section{Continue to strengthen dual professional dual degree work and cultivate a interdisciplinary talent}

According to the demand of high-quality talents for social and economic development, it will continue to give play to the multidisciplinary comprehensive advantages of school, fully mobilize the enthusiasm and initiative of student learning, encourage students who have spare capacity to study minor courses, minor specialty, minor dual specialty and double degree at the same of learning major specialty, broaden the students' knowledge, cultivate the adaptability multi-functional and compound talents with innovative spirit and innovation capability to enhance students' employment competitiveness.

\section{Optimize the curriculum system and improve the overall quality of students}

We should set up quality education selective courses and interdisciplinary and professional elective courses to encourage students to choose courses across disciplines and across majors. We must strive to share the advantages of teaching resources and expand the scope of students' knowledge of different disciplines so that students can be influenced by multidisciplinary knowledge and their overall quality will be continuously improved. ${ }^{[8]}$.

\section{E. Improve the management system of credit system and enhance the autonomy of the students}

We should further improve the credit system management system, establish a credit system management system that adapts to the school personnel training model, create a relaxed learning environment and sufficient conditions, and increase the possibility of students' choice of study and self-designed development direction, goals, and roads, downplay the teaching system and teaching organization form with professional or professional orientation as the core, strengthen the design of teaching programs with the curriculum as the core and the curriculum as the system and establish elective courses and cross-curricular and inter-professional elective courses within the subject or professional category.

\section{ESTABLISH AN INNOVATION PLATFORM FOR TALENT TRAINING AND CULTIVATE STUDENTS' INNOVATIVE AWARENESS}

Cultivating innovative talents is the strategic need of building an innovative nation, and it is also the need to improve the employment competitiveness and independent entrepreneurial ability of college students. Through innovation platform construction, schools should integrate the cultivation of innovative spirit and innovation ability into the whole process of school education, format innovative talent training mode, cultivate applied and compound advanced specialized talents with innovative spirit and innovation ability, so as to make greater contributions to the local economic construction and social development.

The student work department, the Communist Youth League, the research department and the Academic Affairs
Office should jointly construct the student innovation activity organization management mechanism. They should regularly or occasionally hold lectures on innovative skills, innovative thinking methods, and case studies of innovation cases, provide guidance on innovative thinking training and the transformation of innovation results, organize and provide guidance on student innovation activities and establish an innovation center for college students and make them an important place to cultivate students' innovative thinking, innovative ideas, and innovative activities when conditions permit.

In addition, we should establish and improve the student declaration system for innovation issues, explore a set of effective methods for the cultivation, selection, and support of innovative topics, gradually establish and improve the student innovation fund system to reward student innovation, advocate and instill in our students a spirit that faces the future, faces the world, and challenges ourselves and promotes an honest style of study that is down to earth and explores the unknown.

Besides, we should actively guide and vigorously support students to practice internship visits, scientific research and practice activities, organize various forms of student practical skills competitions and extracurricular outcomes competitions (such as contests, debates, art design, foreign language competitions), develop student teamwork spirit and improve their interest in learning, communication ability and innovation ability.

We should keep close contact with relevant social organizations and enterprises, make student innovation activity get more extensive social support in information connection, practice opportunity and practice place, adopt the way of "coming in or going out", strengthen exchanges in student innovation activities with domestic and foreign institutions, learn brother college good experience, and maintain the students' innovative activities at a high level and high tone.

Moreover, we should also closely contact with the provinces (municipalities or autonomous regions) and the various types of competition organizations across the country, and encourage students to actively participate in a variety of higher level competitions and show their style on a larger stage.

\section{Strengthen the Construction of Teaching StafF} in Practical Teaching

The construction of teaching staff in practical teaching is the key to ensure the quality of practical teaching. According to school development, it should determine a proper staff size and equip with enough teachers in the laboratory and technical staff, so as to ensure the normal operation of practical teaching.

Schools should strengthen on-the-job training, plan specialized technical training courses, send some experimental technicians to off-campus training each year, organize a certain number of experimental technicians to go out to study, improve the technical level and management level of experimental technicians, and create high-quality experimental team groups.

School-related functional departments and various hospitals (divisions) shall strengthen the assessment and management of 
experimental technicians, establish a set of evaluation and incentive mechanisms for experimental technicians, regularly perform examinations of experimental technicians, give commendations and awards to personnel with outstanding achievements and give criticism, education, or administrative sanctions for those who have violated the regulations or are dereliction of duties or are irresponsible due to work. ${ }^{[9]}$.

Schools should establish and improve the incentive system for innovative tutors and create a sound environment in which teachers can focus on student innovation, support student innovation, and promote innovation.

\section{SUMMARY}

Practical teaching is a very important part of undergraduate teaching link, and it has an irreplaceable role for cultivating students' practical ability and innovation ability. The quality of practical teaching is an important guarantee for the quality of school talent training. Local colleges and universities should further update educational concepts, establish modern education concepts, teaching concepts, talent concepts and quality concepts, follow the rules of running higher education under the conditions of socialist market economy, be guided by social needs and employment of students, with the focus on the reform of teaching content and the strengthening of practical teaching, and attach great importance to and strengthen practical teaching. Local colleges and universities should also implement the school's idea of running schools, further clarify the school's personnel training objectives and training specifications adhere to education innovation and teaching reform, optimize discipline structure and resource allocation, improve teaching quality and management level, promote quality education and credit system reform and establish a talent quality outlook and talent cultivation model that is compatible with the needs of social development and matches the goal orientation of the school development strategy. In addition, local colleges and universities should reform personnel training programs and training methods so that personnel training programs and approaches are better aligned with personnel training goals and specifications, adhere to the principle of "thick foundation, wide caliber, strong ability, and high quality" and handle well the relationship between the scale and quality of education, professional and compound talents, comprehensive quality and professional knowledge, system theory and practical ability and academic inheritance and academic development in the reform of the talent cultivation model, and strive to cultivate applied and compound talents with innovative spirit and innovative ability to improve teaching quality in an all-round way.

In order to ensure the smooth progress of practical teaching and talent training mode reform, the school and all relevant departments must strengthen the organizational management and institutional management of practical teaching. The functional department of the school practice teaching should be responsible for the macro management of the practice teaching, establish and improve various rules and regulations of practical teaching management and further standardize the management of practice teaching. The leadership of the department must fully understand the status, role, and importance of practical teaching, and be responsible for the overall organization and implementation of practical teaching, strengthen practical teaching work and formulate the specific implementation measures of the department on the basis of the rules and regulations for practical teaching management in schools and professional characteristics of the department, do a good job in planning management, operation management and quality management of practical teaching, solve various problems in practical teaching work, ensure that we can improve students' practical operation level, and cultivate the goal of improving the spirit of innovation and innovation.

\section{REFERENCES}

[1] Weidong Tang, Chen Guo, Changxin Liu, et. al. Research and practice on the training of creative personnel during the construction process of characteristic specialty [J]. Journal of Jinggangshan University, 2009,30(05):121-123+156. (In Chinese)

[2] Yonghui Xu. Analysis of China's university talent training mode reform [J]. Science \& Technology Information. 2010 (34): 146-147. (In Chinese)

[3] Yun Liu. Design and Practice of Practical Teaching System of Applied Accounting Major - A Case Study of Tianfu College of Southwest University of Finance and Economics [J]. Contemporary Accounting, 2017 (07): 68-69. (In Chinese)

[4] Lifen Wang, Jiming Li, Wenxian Wang. An Analysis of Practical Platform for College Students [J]. Theory and Practice of Education, 2014, 34(18): 22-23. (In Chinese)

[5] Xiao Liu. Constructing an Integrated Model of Production, Learning and Research to Cultivate the Employment Ability of University Graduates [J]. Journal of Party School Building and Ideology. 2012 (07): 86-87. (In Chinese)

[6] Honghai Wang \& Wei Su. Study on Practice Teaching System of E-commerce Major in Finance and Economics College [J]. China Management Informationization. 2014, 17 (13): 122-124. (In Chinese)

[7] Hong Liu, Xiangyang Wu \& Chengwu Yi. Practice and Exploration of Environmental Engineering Specialty Construction in Jiangsu University [J]. Education and Careers. 2010 (35): 125-127. (In Chinese)

[8] Hongxia Wu. Create and Practice "Incubation Paradise" to lead students to fly high [N]. China Education News, 2013-12-19 (007). (In Chinese)

[9] Bizhou Ye. Exploration on Strengthening the Practice Teaching Quality Management in Independent Colleges [J]. Science \& Technology Vision. 2015 (13): $160+187$. (In Chinese) 